\title{
Seed Deterioration Pattern of Some China Aster During Storage
}

\author{
Aninda Chakraborty ${ }^{1}$, Sanjoy Kumar Bordolui ${ }^{1}{ }^{*}$, Debarati Nandi ${ }^{2}$ \\ and Manab Kanti Mahato ${ }^{1}$
}
${ }^{1}$ Department of Seed Science and Technology, Bidhan Chandra Krishi Viswavidyalaya, Mohanpur, Nadia, West Bengal-741 252, India
${ }^{2}$ Department of Genetics and Plant Breeding,Bidhan Chandra Krishi Viswavidyalaya, Mohanpur, Nadia, West Bengal-741 252, India

*Corresponding author

\author{
A B S T R A C T
}

\section{Keywords}

China aster, storage, container and deterioration.

Article Info

Accepted:

12 February 2020

Available Online:

10 March 2020
China aster [Callistephus chinensis (Linn.) Ness] belongs to the family Asteraceae, is an important commercial ornamental annual grown in many parts of the world for cut flower, loose flower, bedding plant. The objective of this study was to evaluate the trend in seed deterioration of China aster during storage. The experiments were conducted during 2017-18 in the Seed Testing laboratory, BCKV, Mohanpur, Nadia, West Bengal, India. Seven China aster varieties were store in different storage conditions like Freeze condition $\left(\mathrm{T}_{1}\right)$, Aluminum foil $\left(T_{2}\right)$, Polythene packet $\left(T_{3}\right)$, Earthen pot $\left(T_{4}\right)$, Cloth bag $\left(T_{5}\right)$ and Brown paper $\left(\mathrm{T}_{6}\right)$. Deterioration pattern were observed by checking germination percentage and vigour index change at just after harvesting and every two months interval upto eight months of storage that means the next growing season. Freeze condition is proved to be the best than the other conditions as germination percentage ( 71.83 , $66.93,63.77$ and 61.10, respectively) and vigour index (465.28, 433.88, 414.43 and 450.86 respectively) recorded highest at two months, four months, six months and eight months after storage. So, the Freeze condition can be recommended for storing seeds of China aster with maintenance of better seed quality storage.

\section{Introduction}

From the dawn of civilization flowers are very much interrelated with mankind. India has a long tradition of floriculture. China aster is one of the most important flower crops throughout the world as well as in India also China aster is ranked third next only to chrysanthemum and marigold. It is native to China and it was introduced from China into France by a missionary in the $18^{\text {th }}$ century (Desai, 1967). The present day China asters have been developed from a single form of wild species, Callistephus chinensis. The genus Callistephus is derived from two Greek words Kalistos meaning 'most beautiful' and 
Stephus, 'a crown' referring to the flower head. It belongs to the largest families of flowering plants, 'Asteraceae'. It is an erect, hispid, hairy and branched annual with ovate or triangular ovate leaves spirally attached to the stems (Cockshull, 1985). It is a long day plant (Hughes and Cockshull, 1969) and suitable for intercropping with fruit crops. It is widely cultivated due to its wide spectrum of attractive colours and comparatively longer vase life (Chaitra and Patil, 2007).

It is commercially cultivated in India, France, Germany, Netherlands, U.K., Siberia, Russia, Japan, North America, Switzerland and Europe. In India, it is largely grown on commercial scale in Karnataka, Tamil Nadu, Andhra Pradesh, Maharashtra and West Bengal. Now a day the demand for cut flowers of China aster is increasing every year and for that adaptation of genotypes to varying soil and climatic conditions is important for harnessing the best out of it in a particular area (Mahato et al., 2017).

Evaluation of genotypes, thus, gives an idea for its potential utilization by the growers. In China aster, sufficient numbers of genotypes are under cultivation but their performance related to seed yield varies based on changing agro climatic condition of the growing locations (Chakraborty et al., 2019). The quality of cut flowers as well as seed is primarily a varietal trait and is generally influenced by climatic conditions prevailed during the growing period at a particular place (Singh Rai and Chaudhary, 2016).

It is very essential to study the performance of varieties mainly in relation to seed production and their storability at a particular place (Kumari et al., 2016 and Tejashwi, et al., 2014). The objective of study was to evaluate the seed deterioration pattern of China aster during storage in the gangetic new alluvial zone of West Bengal, India.

\section{Materials and Methods}

Seeds of the seven varieties of China aster (Callistephus chinensis) viz, Arka Aadya $\left(\mathrm{V}_{1}\right)$, Arka Archana $\left(\mathrm{V}_{2}\right)$, Arka Kamini $\left(\mathrm{V}_{3}\right)$, Arka Poornima $\left(\mathrm{V}_{4}\right)$, Local White $\left(\mathrm{V}_{5}\right)$, Local Pink $\left(\mathrm{V}_{6}\right)$, Ranaghat $1\left(\mathrm{~V}_{7}\right)$ were raised in individual plots with three replications. Just after harvesting, the laboratory experiment was done in seed testing laboratory, BCKV, West Bengal during 2017-18.

Harvested seeds were dried and stored in 6\% moisture content in six different conditions namely Freeze condition $\left(\mathrm{T}_{1}\right)$, Aluminium foil $\left(\mathrm{T}_{2}\right)$, Polythene packet $\left(\mathrm{T}_{3}\right)$, Earthen pot $\left(\mathrm{T}_{4}\right)$, Cloth bag $\left(\mathrm{T}_{5}\right)$, Brown paper $\left(\mathrm{T}_{6}\right)$. The different seed quality parameters such as root length shoot length, seedling length, seedling dry weight and fresh weight, germination percentage and vigour index were recorded after harvesting and every two months interval upto eight months storage that means next growing season (Kumari et al., 2017).

Germination test was carried out using germination papers by between papers (BP) method (ISTA, 1985) and calculated as Germination $(\%)=$ No. of normal seedlings germinated $\times 100 /$ Total no. of seeds placed for germination. Vigour Index was also calculated after Abdul-Baki and Anderson (1973) as: Vigour index $=$ Germination $(\%) \times$ root and shoot length $(\mathrm{cm})$.

\section{Results and Discussion}

At just after harvesting of different genotypes root length ranged from $3.72 \mathrm{~cm}$ to $5.28 \mathrm{~cm}$. Longest root length was found in $\mathrm{V}_{5}(5.28 \mathrm{~cm})$ and shortest in $\mathrm{V}_{4}(3.72 \mathrm{~cm})$. Root length varied significantly among the genotypes. Shoot length ranged from $1.76 \mathrm{~cm}$ to $2.40 \mathrm{~cm}$. Highest shoot length was recorded in $\mathrm{V}_{6}$ $(2.40 \mathrm{~cm})$ and lowest in $V_{1}(1.76 \mathrm{~cm})$. Shoot length varied significantly among the 
genotypes. In case of fresh weight, it ranged from $0.83 \mathrm{~g}$ to $0.99 \mathrm{~g}$. Maximum fresh weight was found in $V_{1}(0.99 \mathrm{~g})$ and minimum was found in $V_{6} \quad(0.83 \mathrm{~g})$. Fresh weight significantly varied among the genotypes. Among the genotypes dry weight ranged from $0.07 \mathrm{~g}$ to $0.13 \mathrm{~g}$. In case of dry weight maximum was found in $\mathrm{V}_{4}(0.13 \mathrm{~g})$ and minimum in $\mathrm{V}_{2}$ and $\mathrm{V}_{6}(0.07 \mathrm{~g})$. Dry weight varied significantly among the genotypes. Germination percentage ranged from 81.77 to 94.40 .

With regards to germination percentage highest was found in $\mathrm{V}_{6}$ (94.40) and lowest in $\mathrm{V}_{5}$ (81.77). Non- significant variation among the genotypes was noted for germination percentage at just after harvest or before storage. Among the genotypes vigour index ranged from 485.24 to 662.37 . Highest vigour index was determined in $\mathrm{V}_{6}(662.37)$ whereas lowest was determined in $\mathrm{V}_{3}$ (485.24). Genotypes are not significantly varied among themselves for vigour index. Test weight was from $1.66 \mathrm{~g}$ to $1.82 \mathrm{~g}$. Maximum test weight was found in $\mathrm{V}_{3}(1.82 \mathrm{~g})$ and minimum was found in $\mathrm{V}_{4}(1.66 \mathrm{~g})$. Test weight significantly varied among the genotypes. Similar type of experiment was also done by Moharana et al., 2017.

So, according to storability Local Pink $\left(\mathrm{V}_{6}\right)$ is the best as it shows the high vigour index and germination percentage than other genotypes. After two months of storage, root length varied between $4.40 \mathrm{~cm}$ and $4.42 \mathrm{~cm}$. Highest root length was recorded after $\mathrm{T}_{4}$ and $\mathrm{T}_{6}$ $(4.42 \mathrm{~cm})$ and lowest was found for $\mathrm{T}_{2}$ and $\mathrm{T}_{5}$ $(4.40 \mathrm{~cm})$. Root length significantly varied among the treatments over genotype. Among the treatments over Genotypes, shoot length ranged from $2.06 \mathrm{~cm}$ to $2.08 \mathrm{~cm}$. Maximum shoot length was found for $\mathrm{T}_{1}$ and $\mathrm{T}_{4}(2.08$ $\mathrm{cm}$ ) and minimum shoot was found in $T_{2}$ $(2.06 \mathrm{~cm})$. Shoot length also varied significantly among the treatments. Seedling fresh weight ranged from $0.89 \mathrm{~g}$ to $0.90 \mathrm{~g}$. But, the treatments over genotypes vary significantly among themselves for this parameter. Dry weight ranged from $0.09 \mathrm{~g}$ to 0.10 g. Dry weight of seedling also varied significantly among the treatments over genotypes. Germination percentage varied from 68.29 to 71.83 . The germination percentage was found as maximum (71.83) for $\mathrm{T}_{1}$ and minimum was recorded for $\mathrm{T}_{6}$ (68.29).

It showed significant variation within the treatments over genotypes for germination percentage. The range of vigour index was 441.98 to 465.28. Vigour index was found maximum for $\mathrm{T}_{1}$ (465.28) and minimum value was for $\mathrm{T}_{6}$ (441.98). Treatment over genotype showed nonsignificant variation for vigour index. At two months after storage $T_{1}$ (freeze condition) treatment over genotypes showed the highest germination and vigour index than other treatments over genotypes. So, at two months after storage $T_{1}$ (freeze condition) treatment over genotypes i.e., freeze condition was best.

After four months storage, root length varied between $4.39 \mathrm{~cm}$ and $4.41 \mathrm{~cm}$. Highest root length was recorded in $\mathrm{T}_{3}$ and $\mathrm{T}_{4}(4.41 \mathrm{~cm})$ and minimum was found in $\mathrm{T}_{2}(4.39 \mathrm{~cm})$. Root length significantly varied among the treatments over genotypes. Shoot length ranged from $2.05 \mathrm{~cm}$ to $2.09 \mathrm{~cm}$. Maximum shoot length was found in $\mathrm{T}_{6}(2.09 \mathrm{~cm})$ and minimum shoot was found in $\mathrm{T}_{2}(2.05 \mathrm{~cm})$. Shoot length also varied significantly among the treatments over genotypes. Seedling fresh weight were same for all treatments i.e. 0.89.

The treatments varied significantly among the treatments over genotypes. Dry weight ranged from $0.09 \mathrm{~g}$ to 0.10 . Dry weight of seedling also varied significantly among the treatments over genotypes. Germination percentage varied from 52.17 to 66.93. Germination 
percentage was found maximum as 66.93 in $\mathrm{T}_{1}$ and minimum was recorded in $\mathrm{T}_{6}(52.17)$. It showed significant variation among the treatments over genotypes. The range of vigour index was from 338.17 to 433.88 . Vigour index was found maximum in $T_{1}$ (433.88) and minimum in $\mathrm{T}_{6}$ (338.17). Nonsignificant variation was found among the treatments over genotypes for vigour index.

At four months after storage, $\mathrm{T}_{1}$ (freeze condition) treatment over genotypes showed the highest germination and vigour index than other treatments. So, at four months after storage $\mathrm{T}_{1}$ (freeze condition) treatment over genotypes i.e., freeze condition is best. Treatments over genotypes of root length varied between $4.39 \mathrm{~cm}$ and $4.42 \mathrm{~cm}$. Highest root length was recorded in $\mathrm{T}_{5}(4.42 \mathrm{~cm})$ whereas minimum in $\mathrm{T}_{3}(4.39 \mathrm{~cm})$.

Root length significantly varied among the treatments over genotypes. Treatments over genotypes, shoot length ranged from $2.06 \mathrm{~cm}$ to $2.10 \mathrm{~cm}$. Highest shoot length was found in $\mathrm{T}_{1}(2.10 \mathrm{~cm})$ and lowest in $\mathrm{T}_{6}(2.06 \mathrm{~cm})$. Shoot length also varied significantly among the treatments over genotypes. Seedling fresh weight ranged from $0.89 \mathrm{~g}$ to $0.90 \mathrm{~g}$. The treatments over genotypes vary significantly among themselves for fresh weight. Dry weight ranged from $0.09 \mathrm{~g}$ to $0.10 \mathrm{~g}$. Dry weight of seedling also varied significantly among the treatments over genotypes.

Germination percentage varied from 38.93 to 63.77. Germination percentage was found as maximum in 63.77 for $\mathrm{T}_{1}$ and minimum was recorded in $\mathrm{T}_{6}$ (38.93). Significant variation was recorded among the treatments over genotypes for germination percentage. The range of vigour index was from 250.79 to 414.43. Vigour index was found as maximum in $\mathrm{T}_{1}$ (414.43) and minimum in $\mathrm{T}_{6}(250.79)$.

Table.1 Mean values of root length, shoot length, seedling fresh and dry weight, germination percentage and vigour index of different China aster genotypes just before storage.

\begin{tabular}{|c|c|c|c|c|c|c|c|}
\hline Genotypes & $\begin{array}{c}\text { Root } \\
\text { Length } \\
(\mathbf{c m})\end{array}$ & $\begin{array}{c}\text { Shoot } \\
\text { Length } \\
(\mathbf{c m})\end{array}$ & $\begin{array}{c}\text { Fresh } \\
\text { Weight } \\
(\mathbf{g})\end{array}$ & $\begin{array}{c}\text { Dry } \\
\text { Weight } \\
(\mathbf{g})\end{array}$ & Germination & $\begin{array}{l}\text { Vigour } \\
\text { Index }\end{array}$ & $\begin{array}{l}\text { Test } \\
\text { Weight } \\
(\mathbf{g})\end{array}$ \\
\hline $\mathbf{V}_{\mathbf{1}}$ & 4.63 & 1.76 & 0.99 & 0.10 & 82.43 & 526.41 & $\mathbf{1 . 7 4}$ \\
\hline $\mathbf{V}_{\mathbf{2}}$ & 4.23 & 1.86 & 0.92 & 0.07 & 89.10 & 542.30 & $\mathbf{1 . 6 8}$ \\
\hline $\mathbf{V}_{\mathbf{3}}$ & 3.93 & 1.95 & 0.89 & 0.09 & 82.57 & 485.24 & $\mathbf{1 . 8 2}$ \\
\hline $\mathbf{V}_{\mathbf{4}}$ & 3.72 & 2.18 & 0.92 & 0.13 & 92.27 & 544.73 & $\mathbf{1 . 6 6}$ \\
\hline $\mathbf{V}_{\mathbf{5}}$ & 5.28 & 2.09 & 0.86 & 0.09 & 81.77 & 603.17 & $\mathbf{1 . 7 1}$ \\
\hline $\mathbf{V}_{\mathbf{6}}$ & 4.62 & 2.40 & 0.83 & 0.07 & 94.40 & 662.37 & $\mathbf{1 . 7 4}$ \\
\hline $\mathbf{V}_{\mathbf{7}}$ & 4.44 & 2.30 & 0.89 & 0.11 & 86.40 & 582.83 & $\mathbf{1 . 7 9}$ \\
\hline $\mathbf{S E m}(\mathbf{\pm})$ & $\mathbf{0 . 0 4}$ & $\mathbf{0 . 0 6}$ & $\mathbf{0 . 0 1}$ & $\mathbf{0 . 0 2}$ & $\mathbf{3 . 3 5}$ & $\mathbf{2 0 . 2 3}$ & $\mathbf{0 . 0 4}$ \\
\hline $\mathbf{L S D}(\mathbf{0 . 0 5})$ & $\mathbf{0 . 0 1}$ & $\mathbf{0 . 0 2}$ & $\mathbf{0 . 0 1}$ & $\mathbf{0 . 0 1}$ & $\mathbf{1 . 1 0}$ & $\mathbf{6 . 6 1}$ & $\mathbf{0 . 0 1}$ \\
\hline
\end{tabular}

Arka Aadya $\left(\mathrm{V}_{1}\right)$, Arka Archana $\left(\mathrm{V}_{2}\right)$, Arka Kamini $\left(\mathrm{V}_{3}\right)$, Arka Poornima $\left(\mathrm{V}_{4}\right)$, Local White $\left(\mathrm{V}_{5}\right)$, Local Pink $\left(\mathrm{V}_{6}\right)$, Ranaghat $1\left(\mathrm{~V}_{7}\right)$ 
Table.2 Mean values of root length, shoot length, seedling fresh and dry weight, germination percentage and vigour index of different treatments over genotypes stored in different conditions at two months after storage.

\begin{tabular}{|c|c|c|c|c|c|c|}
\hline Treatment & $\begin{array}{c}\text { Root } \\
\text { Length } \\
(\mathbf{c m})\end{array}$ & $\begin{array}{l}\text { Shoot } \\
\text { Length } \\
(\mathbf{c m})\end{array}$ & $\begin{array}{c}\text { Fresh Weight } \\
(\mathbf{g})\end{array}$ & $\begin{array}{c}\text { Dry } \\
\text { Weight } \\
(\mathbf{g})\end{array}$ & Germination & $\begin{array}{c}\text { Vigour } \\
\text { Index }\end{array}$ \\
\hline $\mathbf{T}_{\mathbf{1}}$ & 4.41 & 2.08 & 0.89 & 0.10 & 71.83 & $\mathbf{4 6 5 . 2 8}$ \\
\hline $\mathbf{T}_{\mathbf{2}}$ & 4.40 & 2.06 & 0.89 & 0.10 & 71.21 & $\mathbf{4 5 9 . 1 3}$ \\
\hline $\mathbf{T}_{\mathbf{3}}$ & 4.41 & 2.07 & 0.90 & 0.10 & 70.53 & $\mathbf{4 5 5 . 8 3}$ \\
\hline $\mathbf{T}_{\mathbf{4}}$ & 4.42 & 2.08 & 0.89 & 0.09 & 69.77 & $\mathbf{4 5 2 . 4 9}$ \\
\hline $\mathbf{T}_{\mathbf{5}}$ & 4.40 & 2.07 & 0.90 & 0.10 & 68.99 & $\mathbf{4 4 5 . 3 2}$ \\
\hline $\mathbf{T}_{\mathbf{6}}$ & 4.42 & 2.07 & 0.89 & 0.09 & 68.29 & $\mathbf{4 4 1 . 9 8}$ \\
\hline $\mathbf{S E m}(\mathbf{\pm})$ & $\mathbf{0 . 0 0}$ & $\mathbf{0 . 0 0}$ & $\mathbf{0 . 0 0}$ & $\mathbf{0 . 0 0}$ & $\mathbf{0 . 0 0}$ & $\mathbf{0 . 2 1}$ \\
\hline LSD(0.05) & $\mathbf{0 . 0 1}$ & $\mathbf{0 . 0 1}$ & $\mathbf{0 . 0 1}$ & $\mathbf{0 . 0 1}$ & $\mathbf{0 . 0 0}$ & $\mathbf{0 . 6 0}$ \\
\hline
\end{tabular}

Freeze Condition $\left(\mathrm{T}_{1}\right)$, Aluminium foil $\left(\mathrm{T}_{2}\right)$, Polythene Packet $\left(\mathrm{T}_{3}\right)$, Earthen pot $\left(\mathrm{T}_{4}\right)$, Cloth bag $\left(\mathrm{T}_{5}\right)$, Brown paper $\left(\mathrm{T}_{6}\right)$

Table.3 Mean values of root length, shoot length, seedling fresh and dry weight, germination percentage and vigour index of different treatments over genotypes stored in different conditions at four months after storage.

\begin{tabular}{|c|c|c|c|c|c|c|}
\hline Treatments & $\begin{array}{c}\text { Root } \\
\text { Length } \\
(\mathbf{c m})\end{array}$ & $\begin{array}{c}\text { Shoot } \\
\text { Length } \\
(\mathbf{c m})\end{array}$ & $\begin{array}{c}\text { Fresh } \\
\text { Weight } \\
(\mathbf{g})\end{array}$ & $\begin{array}{c}\text { Dry } \\
\text { Weight } \\
(\mathbf{g})\end{array}$ & Germination & $\begin{array}{c}\text { Vigour } \\
\text { Index }\end{array}$ \\
\hline $\mathbf{T}_{\mathbf{1}}$ & 4.40 & 2.08 & 0.89 & 0.10 & 66.93 & $\mathbf{4 3 3 . 8 8}$ \\
\hline $\mathbf{T}_{\mathbf{2}}$ & 4.39 & 2.05 & 0.89 & 0.10 & 54.86 & $\mathbf{3 5 2 . 9 0}$ \\
\hline $\mathbf{T}_{\mathbf{3}}$ & 4.41 & 2.07 & 0.89 & 0.10 & 54.01 & $\mathbf{3 4 9 . 6 3}$ \\
\hline $\mathbf{T}_{\mathbf{4}}$ & 4.41 & 2.07 & 0.89 & 0.09 & 53.41 & $\mathbf{3 4 5 . 7 6}$ \\
\hline $\mathbf{T}_{\mathbf{5}}$ & 4.40 & 2.07 & 0.89 & 0.10 & 52.66 & $\mathbf{3 4 0 . 3 4}$ \\
\hline $\mathbf{T}_{\mathbf{6}}$ & 4.40 & 2.09 & 0.89 & 0.10 & 52.17 & $\mathbf{3 3 8 . 1 7}$ \\
\hline $\mathbf{S E m}( \pm)$ & $\mathbf{0 . 0 0}$ & $\mathbf{0 . 0 0}$ & $\mathbf{0 . 0 0}$ & $\mathbf{0 . 0 0}$ & $\mathbf{0 . 0 0}$ & $\mathbf{0 . 1 8}$ \\
\hline $\mathbf{L S D}(\mathbf{0 . 0 5})$ & $\mathbf{0 . 0 1}$ & $\mathbf{0 . 0 1}$ & $\mathbf{0 . 0 1}$ & $\mathbf{0 . 0 1}$ & $\mathbf{0 . 0 0}$ & $\mathbf{0 . 5 1}$ \\
\hline
\end{tabular}

Freeze Condition $\left(\mathrm{T}_{1}\right)$, Aluminium foil $\left(\mathrm{T}_{2}\right)$, Polythene Packet $\left(\mathrm{T}_{3}\right)$, Earthen pot $\left(\mathrm{T}_{4}\right)$, Cloth bag $\left(\mathrm{T}_{5}\right)$, Brown paper $\left(\mathrm{T}_{6}\right)$ 
Table.4 Mean values of root length, shoot length, seedling fresh and dry weight, germination percentage and vigour index of different treatments over genotypes of China aster stored in different conditions at six months after storage

\begin{tabular}{|c|c|c|c|c|c|c|}
\hline Treatments & $\begin{array}{c}\text { Root Length } \\
(\mathbf{c m})\end{array}$ & $\begin{array}{c}\text { Shoot } \\
\text { Length } \\
(\mathbf{c m})\end{array}$ & $\begin{array}{c}\text { Fresh Weight } \\
(\mathbf{g})\end{array}$ & $\begin{array}{c}\text { Dry Weight } \\
(\mathbf{g})\end{array}$ & Germination & Vigour Index \\
\hline $\mathbf{T}_{\mathbf{1}}$ & 4.41 & 2.10 & 0.90 & 0.10 & 63.77 & $\mathbf{4 1 4 . 4 3}$ \\
\hline $\mathbf{T}_{\mathbf{2}}$ & 4.40 & 2.08 & 0.90 & 0.10 & 42.36 & $\mathbf{2 7 3 . 7 3}$ \\
\hline $\mathbf{T}_{\mathbf{3}}$ & 4.39 & 2.06 & 0.90 & 0.09 & 41.53 & $\mathbf{2 6 7 . 2 1}$ \\
\hline $\mathbf{T}_{\mathbf{4}}$ & 4.41 & 2.07 & 0.89 & 0.09 & 40.53 & $\mathbf{2 6 2 . 2 9}$ \\
\hline $\mathbf{T}_{\mathbf{5}}$ & 4.42 & 2.07 & 0.90 & 0.10 & 39.80 & $\mathbf{2 5 7 . 4 7}$ \\
\hline $\mathbf{T}_{\mathbf{6}}$ & 4.39 & 2.06 & 0.90 & 0.10 & 38.93 & $\mathbf{2 5 0 . 7 9}$ \\
\hline $\mathbf{S E m}( \pm)$ & $\mathbf{0 . 0 0}$ & $\mathbf{0 . 0 0}$ & $\mathbf{0 . 0 0}$ & $\mathbf{0 . 0 0}$ & $\mathbf{0 . 0 0}$ & $\mathbf{0 . 1 3}$ \\
\hline $\mathbf{L S D}(\mathbf{0 . 0 5})$ & $\mathbf{0 . 0 1}$ & $\mathbf{0 . 0 1}$ & $\mathbf{0 . 0 0}$ & $\mathbf{0 . 0 1}$ & $\mathbf{0 . 0 0}$ & $\mathbf{0 . 3 6}$ \\
\hline
\end{tabular}

Freeze Condition $\left(T_{1}\right)$, Aluminium foil $\left(T_{2}\right)$, Polythene Packet $\left(T_{3}\right)$, Earthen pot $\left(T_{4}\right)$, Cloth bag $\left(T_{5}\right)$, Brown paper $\left(T_{6}\right)$

Table 5: Mean values of root length, shoot length, seedling fresh and dry weight, germination percentage and vigour index of different genotypes of China aster stored in freeze conditions as other treatments shows germination and vigour index zero at eight months after storage.

\begin{tabular}{|c|c|c|c|c|c|c|}
\hline Genotypes & $\begin{array}{c}\text { Root Length } \\
(\mathbf{c m})\end{array}$ & $\begin{array}{c}\text { Shoot Length } \\
(\mathbf{c m})\end{array}$ & $\begin{array}{c}\text { Fresh Weight } \\
(\mathbf{g})\end{array}$ & $\begin{array}{c}\text { Dry Weight } \\
(\mathbf{g})\end{array}$ & $\begin{array}{c}\text { Germination } \\
\mathbf{\%}\end{array}$ & Vigour Index \\
\hline $\mathbf{V}_{\mathbf{1}}$ & 4.62 & 1.74 & 0.98 & 0.15 & 59.90 & $\mathbf{3 8 0 . 9 6}$ \\
\hline $\mathbf{V}_{\mathbf{2}}$ & 4.20 & 1.88 & 0.91 & 0.10 & 60.20 & $\mathbf{3 6 6 . 2 2}$ \\
\hline $\mathbf{V}_{\mathbf{3}}$ & 3.96 & 1.92 & 0.92 & 0.09 & 59.70 & $\mathbf{3 5 0 . 8 4}$ \\
\hline $\mathbf{V}_{\mathbf{4}}$ & 3.04 & 1.84 & 0.91 & 0.11 & 60.50 & $\mathbf{2 9 5 . 0 4}$ \\
\hline $\mathbf{V}_{\mathbf{5}}$ & 5.25 & 2.15 & 0.87 & 0.09 & 60.90 & $\mathbf{4 5 0 . 8 6}$ \\
\hline $\mathbf{V}_{\mathbf{6}}$ & 4.70 & 2.34 & 0.81 & 0.08 & 61.10 & $\mathbf{4 2 9 . 9 4}$ \\
\hline $\mathbf{V}_{\mathbf{7}}$ & 4.50 & 2.39 & 0.89 & 0.10 & 60.60 & $\mathbf{4 1 7 . 7 4}$ \\
\hline $\mathbf{S E m}( \pm)$ & $\mathbf{0 . 2 6}$ & $\mathbf{0 . 0 1}$ & $\mathbf{0 . 0 1}$ & $\mathbf{0 . 0 1}$ & $\mathbf{0 . 0 9 5}$ & $\mathbf{1 5 . 2 3}$ \\
\hline $\mathbf{L S D}(\mathbf{0 . 0 5})$ & $\mathbf{0 . 7 8}$ & $\mathbf{0 . 0 2}$ & $\mathbf{0 . 0 2}$ & $\mathbf{0 . 0 0 4}$ & $\mathbf{0 . 2 9 1}$ & $\mathbf{4 6 . 8 2}$ \\
\hline
\end{tabular}

Arka Aadya $\left(\mathrm{V}_{1}\right)$, Arka Archana $\left(\mathrm{V}_{2}\right)$, Arka Kamini $\left(\mathrm{V}_{3}\right)$, Arka Poornima $\left(\mathrm{V}_{4}\right)$, Local White $\left(\mathrm{V}_{5}\right)$, Local Pink $\left(\mathrm{V}_{6}\right)$, Ranaghat $\left(\mathrm{V}_{7}\right)$ 

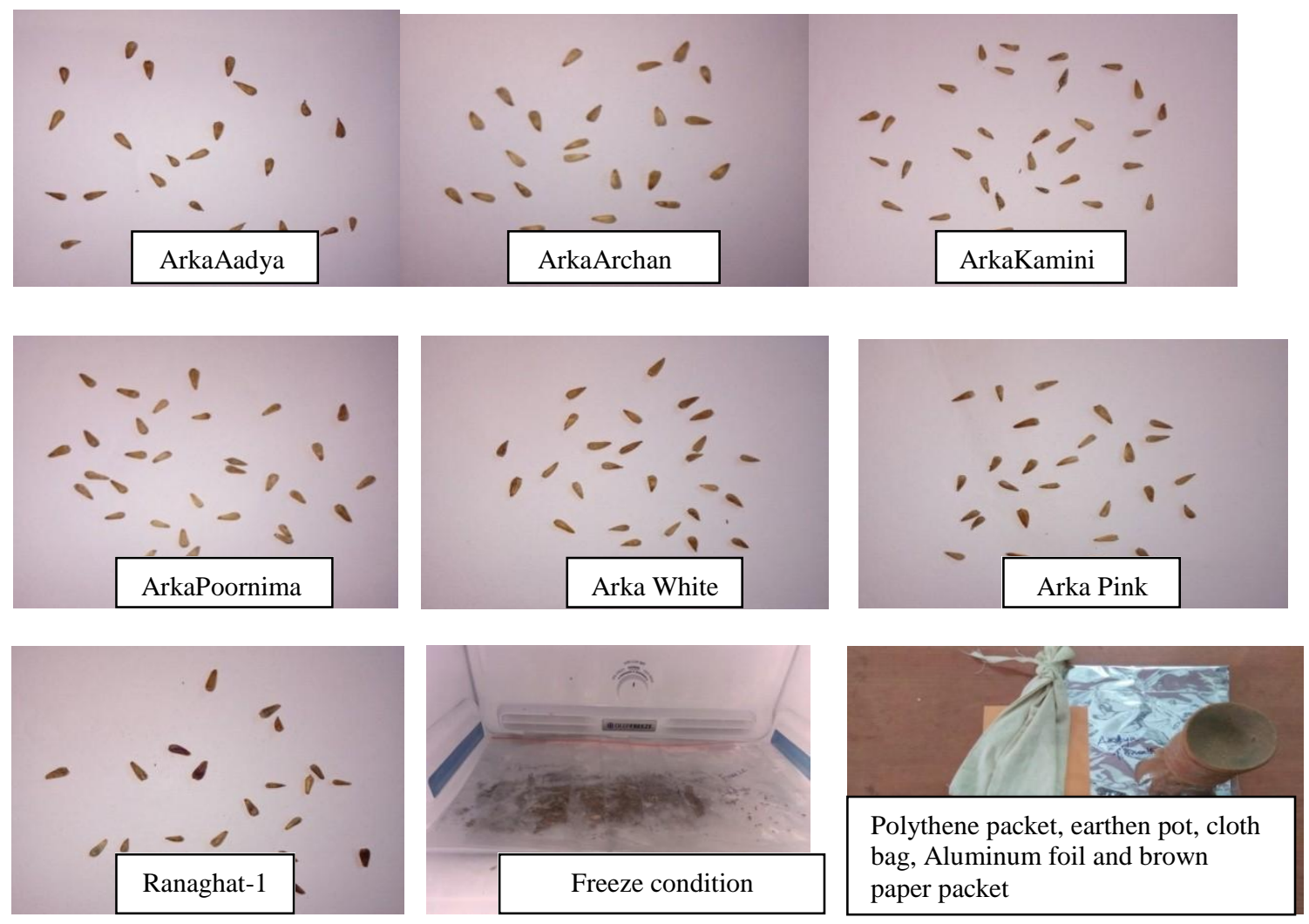

Fig.1 Seeds of different varieties of China aster and different storage containers

Non-significant variation was seen among the treatments over genotypes for vigour index. At six months after storage $\mathrm{T}_{1}$ (freeze condition) treatment over genotypes showed the highest germination and vigour index than other genotypes. So, at six months after storage $\mathrm{T}_{1}$ (freeze condition) treatment over genotypes i.e., freeze condition is best.

After eight months storage, seed germination observed only in freeze condition stored seed of China aster but it was zero for any other condition. That means the other parameters like root length, shoot length, fresh weight, dry weight and vigour index were also zero for other treatments. Genotypes stored in freeze condition after eight months storage, root length ranged from $3.04 \mathrm{~cm}$ to $5.25 \mathrm{~cm}$ among the genotypes over freeze condition. Maximum root length was found in $V_{5}$ $(5.25 \mathrm{~cm})$ and minimum in $\mathrm{V}_{4}(3.04 \mathrm{~cm})$. Shoot length ranged from $1.74 \mathrm{~cm}$ to $2.39 \mathrm{~cm}$. Longest shoot length was recorded in $V_{7}$ $(2.39 \mathrm{~cm})$ and shortest mean value was noted in $\mathrm{V}_{1}(1.74 \mathrm{~cm})$. Fresh weight was from $0.81 \mathrm{~g}$ to $0.98 \mathrm{~g}$. Maximum fresh weight was found in $\mathrm{V}_{1}(0.98 \mathrm{~g})$ and minimum in $\mathrm{V}_{6}(0.81 \mathrm{~g})$.

Among the genotypes over freeze condition dry weight ranged from $0.08 \mathrm{~g}$ to $0.15 \mathrm{~g}$. Maximum dry weight was found in $\mathrm{V}_{1}$ $(0.15 \mathrm{~g})$ and minimum in $\mathrm{V}_{6}(0.08 \mathrm{~g})$. In case of germination percentage, it ranged from 59.70 to 61.10. Highest germination percentage was found in $\mathrm{V}_{6}(61.10)$ whereas lowest in $V_{3}$ (59.70). Among the genotypes stored in freeze condition vigour index varied within a range from 295.04 to 450.86 . Maximum vigour index was determined in $\mathrm{V}_{5}$ (450.86) and minimum in $\mathrm{V}_{4}$ (295.04). So, according to storability Local White $\left(\mathrm{V}_{5}\right)$ is the best genotypes as it shows the high vigour 
than other genotypes and in case of germination, it is second highest. Local Pink $\left(\mathrm{V}_{6}\right)$ shows best performance in storing condition as it continuously performs better than other genotypes from just before storage to eight months after storage. Freeze condition is the best over the other conditions as germination percentage $(71.83,66.93$, 63.77 and 61.10 , respectively) and vigour index (465.28, 433.88, 414.43 and 450.86 respectively) recorded highest at two months, four months, six months and eight months after storage.

\section{References}

Abdul-Baki, A. A. and Anderson, J. D. 1973. Vigor determination in soybean seed by multiple criteria. Crop science, 13(6): 630-633.

Chaitra, R. and Patil, V. S. 2007. Integrated nutrient management studies in Chin aster [Callistephus chinensis (L.) Nees]. Karnataka J. of Agriculture Science. 20(3): 689-690.

Chakraborty, A., Bordolui, S.K., Mahato, M. K., Sadhukhan, R. and Sri Veda, D.J.M.S.N.K., 2019.Variation in seed production potential of China aster genotypes in the New Alluvial Zone of West Bengal. J. of Crop and Weed.15(1): 201-204.

Cockshull, K. E. 1985. Callistephus chinensis. In: A. H. Halevy (ed.) CRC Handbook of Flowering. Volume II. CRC Press Inc., U. S. A.

Desai, B. L. 1967. Flower description of China aster (Callistephus chinensis).
Hughes, A. P. and Cockshull, K. E. 1969. Growth and dry weight distribution in Callistephus chinensisas influenced by lighting treatment. Annuals of Botany. 33(2): 367-379.

ISTA 1985. International rule for seed testing. Seed Sci. Tech., 13:299-55.

Kumari, P., Bordolui, S. K. and Sadhukhan, R. 2016. Seed and seedling quality evaluation of some winter flower in New Alluvial Zone. J. Crop and Weed. 12(3): 23-26.

Kumari, P., Bordolui, S. K. and Sadhukhan, R. 2017. Seed quality deterioration of some winter flowers during storage. $J$. Crop and Weed. 13(1): 164-169.

Mahato, M. K., Bordolui, S. K., Sadhukhan, R. and Moharana, R. L., 2017. Evaluation of seed production potential of China Aster in new alluvial zone. The Bioscan. 12(3): 1649-1652, 2017 (Supplement on Agronomy).

Moharana, R. L., Basu, A. K., Bordolui S. K. and Hembram, A. K. 2017. Packaging materials for seed storage in Indian bean - Genotypic response. J. Crop and Weed, 13(2): 60-63.

Singh Rai, T. and Chaudhary, S. V. S. 2016. Evaluation of China aster (Callistephus chinensis (L) nees.) cultivars under mid hill conditions of Himachal Pradesh. The Bioscan. 11(4): 2367-2330. (Supplement on Agronomy).

Tejashwi P. K., Asha, A. M. , Maruthi, J. B. and Vishwanath, K. 2014. Influence of seed treatment chemicals and containers on seed quality of marigold during storage. The Bioscan. 9(3): 937-942

\section{How to cite this article:}

Aninda Chakraborty, Sanjoy Kumar Bordolui, Debarati Nandi and Manab Kanti Mahato. 2020. Seed Deterioration Pattern of Some China Aster During Storage. Int.J.Curr.Microbiol.App.Sci. 9(03): 1499-1506. doi: https://doi.org/10.20546/ijcmas.2020.903.175 